University of Chicago Law School

Chicago Unbound

Journal Articles

Faculty Scholarship

1943

\title{
Methods of Legal Thought and the Conflict of Laws: A Book Review
}

Max Rheinstein

Follow this and additional works at: https://chicagounbound.uchicago.edu/journal_articles

Part of the Law Commons

\section{Recommended Citation}

Max Rheinstein, "Methods of Legal Thought and the Conflict of Laws: A Book Review ," 10 University of Chicago Law Review 466 (1943).

This Article is brought to you for free and open access by the Faculty Scholarship at Chicago Unbound. It has been accepted for inclusion in Journal Articles by an authorized administrator of Chicago Unbound. For more information, please contact unbound@law.uchicago.edu. 


\title{
METHODS OF LEGAL THOUGHT AND THE CON. FLICT OF LAWS: A BOOK REVIEW*
}

\author{
Max RHEINSTEIN†
}

$\mathrm{F}$ OR many years, Walter Wheeler Cook has been publishing articles on various problems of the conflict of laws, articles which have distinguished him as an incisive critic of the methods applied and the solutions reached in the American Law Institute's Restatement of the Law of Conflict of Laws. The articles have appeared at long intervals and have been scattered over several law reviews. In the present volume all eleven are assembled, brought down to date by "Supplementary Remarks I942" and augmented by seven new essays. The new volume obviously is not intended to constitute a comprehensive treatise on the conflict of laws. Yet, its various parts show consistent unity of thought. Their coherence cannot be appreciated, however, unless one realizes that the author is not concerned primarily with the conflict of laws. Rather, he has attacked the role of logic in legal thought, and chosen the conflict of laws merely as a field of illustration. The choice is apt, since faulty logic has had even more pernicious results here than in other fields. In analyzing the logical fallacies in the conflict of laws, Professor Cook not only has shown lawyers how better to use their mental tools in all fields of the law, but he also has destroyed those fanciful structures which have prevented a needed reconstruction in the field of conflict of laws.

The mistakes and fallacies attacked by Professor Cook are embodied principally in the Restatement and in the treatise which Professor Beale, the Reporter, wrote in amplification and explanation thereof. Beale's work possesses an imposing unity. Several hundred separate "rules" are presented as logical derivations from a few premises which are regarded as self-evident truths. The centerpiece is the so-called territorial theory of the conflict of laws. It is stated by Professor Cook as follows:

I. Every nation possesses an exclusive sovereignty and jurisdiction within its own territory.

2. The laws of every state affect and bind directly all property, whether real or

* Walter Wheeler Cook, The Logical and Legal Bases of the Conflict of Laws. Harvard Studies in the Conflict of Laws: Volume V. Cambridge, Mass.: Harvard University Press, I942. Pp. xx, 468. \$5.00. Arthur Nussbaum, Principles of Private International Law. New York: Oxford University Press, I943. Pp. xvi, 288. \$3.50.

$\dagger$ Max Pam Professor of Comparative Law, University of Chicago; visiting Professor of Law and Political Science, University of Puerto Rico. 
personal, within its territory, and all persons who are resident within it, . . . and also all contracts made and acts done within it.

3. No state or nation can by its law directly affect or bind property out of its territory, or bind persons not resident therein. ${ }^{x}$

These postulates, taken by Beale from Story's famous treatise, ${ }^{2}$ are shown by Mr. Cook to be both ambiguous and inconsistent. The elaborate proof starts with the statement of a fourth postulate, shown to be implied in the preceding three and formulated as follows: "Jurisdiction can be exercised separately over 'persons' and over 'things'; an exercise of jurisdiction over one of these does not involve at the same time exercise of it over the other." 3

Thus stated, the proposition readily reveals its underlying fallacy: That jurisdiction cannot be exercised over a thing or over an act without necessarily affecting persons is obvious as soon as the vague term "exercise of jurisdiction" is more closely defined as the exercise of governmental authority through such officers as sheriffs.

The "exclusive sovereignty and jurisdiction which a nation is said to possess within its own territory" is shown not to derive from any mysterious intrinsic nature of things but simply from the present political arrangement of the world under which every nation, during peacetime, refrains from having its officials exert any physical exercise of governmental power within the territory of another nation. Furthermore, Mr. Cook proves convincingly that international law is in no way violated by a judicial application of domestic rules to acts or events occurring within another nation or state. If courts frequently "apply" to foreign events rules other than those which they apply to domestic facts, they do so only for reasons of social policy. This fact has been obscured, however, by the belief in purported necessities and the attempt to develop by logical inference the entire structure of the conflict of laws from a few basic postulates which, upon analysis, turn out to be untenable. Consequently, the results reached contradict sound social policy in many respects and would never have been arrived at had the courts been left to consider the interests and policies at stake in concrete situations.

This is the charge which is launched by Mr. Cook against the StoryBeale approach. The workings of that approach are traced elaborately, if sometimes laboriously, through the various important fields of the con-

I Cook, op. cit. supra note ${ }^{*}$, at 5 I.

${ }^{2}$ Each chapter of Mr. Cook's book is introduced by some apt motto or quotation. Preceding the chapter on Story's treatment of capacity to marry, we find the following Shakespearean line: "The evil that men do lives after them; the good is oft interred with their bones."

3 Cook, op. cit. supra note ${ }^{*}$, at 52 . 
flict of laws, especially torts and contracts, where they have begotten the vicious "vested rights" theory and the equally unfortunate doctrine that contracts are "governed" by the law of the place of contracting.

This elaborate analysis of the Story-Beale theories, however, is used only to illustrate an even broader and more basic problem, viz., the influence of ambiguous language upon legal thought. If the title had not been pre-empted by Stuart Chase, Mr. Cook might fittingly have called his book "The Tyranny of Words."

The tendency to assume that a word which appears in two or more legal rules, and so in connection with more than one purpose, has and should have precisely the same scope in all of them runs all through legal discussions. It has all the tenacity of original sin and must constantly be guarded against.4

Patiently and elaborately Mr. Cook demonstrates how often this obvious truth has been disregarded in dealing with such terms as domicile, substance and procedure, movable and immovable, place of contracting, illegality and, worst of all, law.

An examination of the history of human thought, whether in the field of philosophy, of logic, or of science, will reveal that often what at first sight seem to be difficult or insoluble problems prove not to be problems at all: the seeming problems have been generated by unfounded assumptions or the use of misleading and ambiguous language. 5

The tortured problems of "characterization" and "renvoi" are used by Mr. Cook as prize illustrations of this point.

His long battle against the Bealian approach has caused Mr. Cook commonly to be ranked among the so-called realists. The struggle which the "realists" have been waging with the so-called conceptualists has created the impression that "realism" would dispense with the use of logic in legal thought. That impression has been strengthened by a good many statements of realists themselves and, particularly, by the fashionable tendency constantly to refer to Mr. Justice Holmes's much abused bon mot, "The life of the law has not been logic, it has been experience." Mr. Cook refutes the deprecators of logic. Time and again he feels compelled to reiterate the truth which should be obvious, viz., that logic is simply the study of the general conditions of valid inference without which no consistent thinking would be possible at all.

Dean Pound has written much about "mechanical jurisprudence," a "jurisprudence of conceptions." Of course in a very real sense all jurisprudence is one of "conreptions." What frequently is happening in the cases Dean Pound refers to is, it is believed, that a court will unthinkingly assume that a definition given to a word in one legal rule is to be followed blindly when the same word appears in a different rule

\footnotetext{
4 Ibid., at I59. $\quad 5$ Ibid., at 2 II.
} 
having a different social, economic, or political purpose. To do this is not, as one might at first sight conclude, "the extension of a maxim or a definition with relentless disregard of consequences to 'a dryly logical extreme." "' Only after one has made the indefensible assumption that the definition of the word given in one rule is applicable without further thought in connection with a different rule, can there be even an appearance of logic.?

In a statement which does not form a part of the present book, ${ }^{8}$ the author aptly describes his position as follows: "It is not for a moment suggested that rules and principles are to be ignored or discarded, but merely that their formulation, selection, use, and possible refinement should be carefully worked out in the light of the social and economic purposes in view." It is not the use of logic or of rules or concepts which Mr. Cook is fighting, but the use of faulty, undisciplined logic and of inadequately formulated rules and concepts. Neither does Mr. Cook share the prejudice of some disciples of "semantics," who seem to think that logic and an analysis of the meaning of words will by themselves solve all our problems. "All that is suggested is that the analysis in question is necessary, not that it is sufficient."' It must go together with an examination and evaluation of the interests at stake.

To undertake the proposed analysis consistently for every conflicts problem discussed has obviously been regarded by the author as exceeding the task of the present book. Frequently, however, he indicates the general directions which such an inquiry ought to take and in places it is carried on by himself. To this reviewer, who has long advocated a more extended resort to the law of the domicile with respect to such problems as capacity to marry, capacity of married women to make contracts, or permissibility of personal injury suits between husband and wife, it is gratifying to see that Professor Cook's searching inquiries point toward the same direction. The reviewer also finds himself in accord with Professor Cook's advocacy of the rule according to which contract problems are to be resolved in the first place by the law which the parties themselves have chosen.

Much of Mr. Cook's book sounds commonplace. Of course, it is. The conditions of consistent thought were discovered long ago. But they have been forgotten and disregarded in many fields of human endeavor, in po-

\footnotetext{
${ }^{6}$ Cardozo, J., in Hynes v. New York Central R. Co., 23I N.Y. 229, 235, x3I N.E. 898, 900 (I92I).

7 Cook, op. cit. supra note *, at 167 .

${ }^{8}$ Cook, The Logical and Legal Bases of the Conflict of Laws-An Unpublished Chapter: In Conclusion, 21 Can. Bar Rev. 249, 253 (1943).
}

9 Cook, op. cit. supra note $\mathrm{x}$, at 293 . 
litical rhetoric as well as in learned discussions of the problems of conflict of laws. When we have become more acutely aware of the role logical fallacies have been playing in law and, especially, in conflict of laws, let us not forget that that awareness is to a large extent owing to the writings of $\mathrm{Mr}$. Cook. Although much awareness is discoverable among some of the younger writers, it is far from general. The courts, particularly, are still under the spell of the great names that have given an aura of authoritativeness to an untenable methodology. There has been definite progress, however, in the formulation of the methods of inquiry. With the refinements of the scientific techniques of thought, Professor Cook is intimately familiar, and in applying them to legal problems he has put them to good and novel use.

Bad logic and lack of precision in the use of language have wrought havoc not only in the conflict of laws of the common law countries: Striking parallels can be found in European continental thought. Since the turn of the century, however, the faulty use of concepts in legal thought generally and in the conflict of laws in particular has been under attack in Europe, especially in France and Germany. Such scholars as Geny in France and Heck, Lewald, and others in Germany have engaged in searching inquiries. The national isolation of legal scholarship is strikingly illustrated by the fact that it was necessary for an American scholar to duplicate this work for his legal system in complete independence of his European colleagues. ${ }^{\text {Io }}$ Abroad, the analysts have already been followed

10 Familiarity with these writings or with certain concepts which have been common coin in continental jurisprudence for centuries might have been suggestive in several respects. In his polemic against the pre-conceived notion that parties are "necessarily" unable to determine by their stipulation the law by which disputes arising out of their agreement should be decided, the author could have found suggestive ideas not only in the modern writings of Lewald, $M$. Wolff, Haudek, or Rabel, but also in the venerable doctrine of itus dispositioum (stop-gap law). Answering those authors who deny to private parties the power of "substituting" for the law "properly applicable" to their contract the law of some other state, Mr. Cook states numerous situations where private parties are "allowed" by their agreement to change the rules which would "properly" determine their legal relation. Among these illustrations we find, for instance, the power of the parties to a bailment or a contract of transportation by agreement to alter what would otherwise be their relative rights and duties; or the power to make by agreement unassignable "rights which normally would be assignable." One wonders why he does not find in Mr. Cook's list such powers as those of the parties to a sale by agreement to "alter" the "normal" rules about place and time of performance, warranties, measure of damages, or impossibility; or the power of a property owner to alter, by making a will, the "normal" course of descent of his property; or the power of a testator, by appropriate clauses, to "alter" the "normal" rules on ademption and abatement of legacies or application of assets. If we survey the vast range of such powers, we might well pause to consider whether we should not look upon the "normal" rules of law applying in such cases as rules of subsidiary application which ought not to be resorted to at all unless the parties have failed to state their own rule. Under the principles of freedom of contract and freedom of testation it is up to the parties concerned to say what they intend to be done. Within certain limits established by those rules which the Roman jurists long ago called ius strictum and which we might properly 
by the builders of a new system of conflict of laws, a system which tends to derive its concepts not from abstract postulates of purported self-evident validity but from the actual problems of life. In the present holocaust their work has been eclipsed, but acquaintance with it might facilitate the task for which Mr. Cook has prepared the ground.

This very wealth of ideas developed and experiences gathered in European conflict of laws has been made accessible to American readers in Professor Arthur Nussbaum's new book. ${ }^{x}$ This author is already known to American readers through his book on Money in the Lawe ${ }^{x^{2}}$ and by a number of articles on topics of commercial law, ${ }^{13}$ conflict of laws, ${ }^{14}$ and other fields. ${ }^{15} \mathrm{Be}$ fore he came to this country ten years ago, Professor Nussbaum had long been known in Germany as a popular teacher, a stimulating scholar, and an influential writer. Throughout his long academic career, Professor Nuss-

call "framework" law, the properly manifested intention of the parties is the law of the case. Only where they have failed to provide for a contingency which has arisen and for which they should have provided, and probably would have provided had they ever thought of it, will those rules be applied which are held in store to fill the gap. Failure to recognize this nature of a large, or, better, the major part, of all the rules of the law of contracts, wills, and certain other fields, has resulted in many difficulties and injustices and has been the main cause of the unsatisfactory state of the law of future interests. When seen as an application of a general principle of considerably wider application, the stipulation by the contracting parties that disputes arising out of the contract shall be decided under the law of a certain state, this power appears not so much one of altering the law that would "properly" be applicable, but rather one of making that determination which it is the very parties' task to make. Then it also becomes apparent that for those cases where the parties have failed to make the determination of the law applicable to eventual disputes between them, a rule of stop-gap law is necessary. A vast amount of the confused discussions as to "implied intention" of the parties as well as of those dealing with the question of whether a contract ought to be "governed" by the law of the place of contracting or by the law of the place of performance, or by some other law, would be clearer were we aware that what we are doing in these cases is deciding, probably quite arbitrarily, what the rule of stop-gap law is to be.

Is Nussbaum, op. cit. supra.

12 Nussbaum, Money in the Law (1939).

${ }_{33}$ Comparative Aspects of the Anglo-American Offer and Acceptance Doctrine, $36 \mathrm{Col}$. L. Rev. 920 (1936); Acquisition by a Corporation of Its Own Stock, 35 Col. L. Rev. 97 I (I935); Basic Monetary Conceptions in Law, 35 Mich L. Rev. 865 (1937); Multiple Currency and Index Clauses, 84 U. of Pa. L. Rev. 569 (I936); American and Foreign Stock Exchange Legislation, 21 Va. L. Rev. 839 (I935); The Law of the Dollar, 37 Col. L. Rev. I057 (r937); The Meaning of Inflation, 58 Pol. Sci. Q. 86 (1943).

14 Comparative and International Aspects of American Gold Clause Abrogation, 44 Yale L. J. 53 (1934); International Legal Effects of Dollar Depreciation, 2 Univ. Chi. L. Rev. 29I (1935); Public Policy and the Political Crisis in the Conflict of Laws, 49 Yale L. J. Io27 (1940); Treaties on Commercial Arbitration, 56 Harv. L. Rev. 219 (I942); Conflict Theories of Contracts: Cases Versus Restatement, 5I Yale L. J. 893 (I942); Rise and Decline of the Law of Nations Doctrine in the Conflict of Laws, 42 Col. L. Rev. I89 (1942); The Problem of Proving Foreign Law, 50 Yale L. J. I018 (I94I).

5 Liberty of Testation, 23 A.B.A.J. 183 (1937); Sociological and Comparative Aspects of the Trust, 38 Col. L. Rev. 408 ( 1938 ). 
baum has kept in close touch with the practice of law and the course of business. This combination of interests has caused him always to treat the law in its practical applications rather than to look upon it as a selfsufficient system of rules, statutes, or precedents. His investigations into the actual working of the law in such fields as mortgages, life estates, marital property rights, and commercial arbitration have distinguished him as a leader of the movement of pre-National Socialist German legal thought which so closely parallels the American reaction against fallacious conceptualism which has taken place under the names of sociological jurisprudence and (moderate) realism. ${ }^{16}$ In the field of German conflict of laws, dealt with by Professor Nussbaum in a most readable, comprehensive modern treatise, ${ }^{17}$ such a method was as badly needed as it is now in the United States.

Mr. Nussbaum's present work represents a type infrequently encountered in the literature of the common law. It does not belong to the digest type of treatise where authorities are assembled, exhaustively and exhaustingly, and simply placed before the reader. In accordance with the best traditions of European legal learning, Mr. Nussbaum presents the guiding principles of the law, not as a theorist's preconceived structures, however, but as they underlie the authorities or as they are derived from the various unsolved problems.

However, no attempt is made by this method to cover the entire field of conflict of laws. The author has rather chosen a number of problems, which either appear to him of great practical importance or which have constituted focal points of theoretical discussion. Thus, in the first part, entitled "Private International Law in General," Mr. Nussbaum surveys the history of the topic, the "theories" by which it was inspired and guided, and the general characteristics and constitutional bases of the conflict of laws of the United States. The second part, entitled "The Choice-ofLaw Rule," deals with that branch of the conflict of laws which determines the country or state, the law of which should be applied in a given situation. Discussed first are the general choice-of-law problems, viz., qualification (or characterization), renvoi, preliminary questions, public policy, personal law (including domicile and nationality), and formalities of transactions. These sections are followed by three sections dealing with the choice-of-law in the field of contracts. In the third part, the author discusses the principal procedural problems of the conflict of laws, viz., jurisdiction, foreign judgments, proof of foreign law, foreign parties, let-

${ }^{36}$ Compare his article, Fact Research in Law, 40 Col. L. Rev. I89 (I940).

${ }^{77}$ Nussbaum, Deutsches internationales Privatrecht (1932). 
ters rogatory and related topics, and foreign aspects of exemption laws. In the choice of these topics there is apparent a certain predilection for those problems most frequently encountered in interstate or international business transactions and in litigation arising therefrom. Problems of family law or decedent estates are touched upon only incidentally, and those of torts are hardly mentioned. The attentive reader, however, will find in the book many suggestive ideas to help him find his way through the authorities dealing with these topics.

Although a model in comparative law, the book is definitely a book on American law. The American conflict of laws is simply presented against a European background. Problems of conflict of laws are by and large the same all over the world. Through Lord Mansfield, Story, Dicey, Phillimore, Beale, Lorenzen, and others, English and American discussions have kept contact with the thought and practice of the civil law countries. Only in comparatively recent times has this interchange of ideas been interrupted. American thought on conflict of laws lost touch with the European just when the latter was shifting from the theorizing of the late Igth and early zoth century to its vigorous new "realism." The literature of republican Germany, of France and Italy, and the creative and eminently "sound" practice of the courts of these countries as well as of the tribunals of the Netherlands, Switzerland, and the Scandinavian countries, have scarcely been known in the United States. This wealth of material has now been opened up and its pertinence and suggestiveness for America demonstrated by Professor Nussbaum. Because Mr. Nussbaum perceives the fallaciousness of the so-called international theory of conflict of laws, he avoids any attempt simply to transplant European ideas and solutions to American soil. He emphasizes that conflict of laws, like any other branch of the law, is national in character, and thus bound to embody the policies and ideals of the particular country. Hence, foreign ideas are suggestive only in so far as the policies of the foreign nation resemble our own, or as they indicate the extent to and the means by which different national policies are pursued in different countries. The author's awareness of this fact appears throughout his book, particularly in his chapter on public policy. Contrary to most writers, he advises courts to make a more vigorous use of this concept of public policy for the purpose of balancing the policy of international uniformity of decision against other equally, or sometimes more, important policies of the forum.

The coverage of this wide range of problems and material has been miraculously condensed into less than three hundred pages. Although packed with "meat," the book is not difficult to read. The author dis- 
plays a remarkable felicity of expression, a fine gift of discrimination between the important and the accidental, and great skill in referring the reader to other sources for elaborations of various points. Footnotes are used intelligently, though with moderation. A surprisingly large number of American cases, many of them neglected in other books, are cited and commented upon.

These features make the book particularly appropriate for student use, not instead of a casebook, but as a worth-while supplement. When thus used, the book will not only help the student to understand the problems better, but also to see them in new, suggestive connections. The practitioner may not always find in the book the case squarely in point; for that purpose, he had better turn to a digest. But he will find helpful ideas and a release from the strait jacket within which the Restatement has tried to confine the American conflict of laws. 'Criticism of the Restatement is a conspicuous feature of Mr. Nussbaum's book, criticism thoroughly grounded upon American cases and upon considerations of sound practice and experience.

In accord with the trend of German law of the republican period, Professor Nussbaum objects to all preconceived theories. For more than half a century, European conflict of laws was influenced and handicapped by the notion that conflict of laws was a part of, or at least based upon, international law. This idea found expression in the very term "private international law," by which the subject has come to be called in French, Italian, and other romance languages. ${ }^{18}$ According to that theory, international law imposes upon all nations a duty to apply identical or nearly identical rules of conflict of laws. The most eminent representatives of this school attempted to prove that such an internationally uniform system of conflict of laws existed already. Decisions of courts which did not conform to the individual author's ideas were either ignored or criticised as "wrong." The theory was an expression of that noble spirit of international liberalism which permeated the late nineteenth century. Its illusory character was demonstrated by World War I. The theory upon which the Restatement of the American law is based and which, through the ceaseless efforts of Mr. Beale, has exerted such a deep influence upon American courts, is but a peculiar variant of the international theory. For unexplained reasons it is assumed that each sovereign state has exclusive power to regulate the conduct of persons, the legal status of things, and

${ }^{18}$ The term "international private law," usually applied to this field in German, does not have this connotation. The author's preference for that term over the term "conflict of laws" is explained in the first section of his book. 
the legal consequences of acts performed, within its territory. W. W. Cook, Lorenzen, and others have shown that these assumptions are unfounded, that they are intrinsically contradictory, and that they result in "unsound" decisions. All such theories, together with their offspring, the "vested rights theory" and the "place of contracting theory," are vigorously rejected by Professor Nussbaum.

His approach is practical. Conflict of laws is, first, national law, and, second, a means toward the reasonable solution of practical problems. Reasonableness and practicability, then, are the tests which he uses. Particularly are these tests applied to problems of renvoi and qualification which in recent years have borne so much tortured discussion, most of it more confusing than helpful to the bench and bar. ${ }^{\text {I9 }}$ Among several approaches to or solutions of a problem, Mr. Nussbaum consistently prefers that which is best suited to interstate or international business, provided, always, that it accords with the policies of the forum. Respect for the latter is shown in the author's comparison of the nationality principle with that of the domicile, and in his treatment of "public policy." The "homeward trend" displayed by so many decisions which, by one means or another, result in the application of the forum's own internal law, is taken as a phenomenon to be reckoned with, and the author's own treatment of the renvoi problem is inspired by it. The author's experience in the international practice of law has developed in him a keen sense for the limitations of feasibility. Theories so fine-spun that their application is beyond the ken of an average court are rejected as impracticable; most of what has been written under the heading of qualification falls under that censure. His familiarity with international litigation has obviously induced the author to include within the rigidly limited compass of his book such practically important topics as foreign parties and proof of foreign law, topics not regularly discussed in books on conflict of laws.

Readers will differ with respect to the topics which they would like to see covered by a book as short as this. To this reviewer Mr. Nussbaum's choice appears, on the whole, felicitous. There is only one topic the scant treatment of which is to be regretted, viz., the inclination of European courts to split up a single case into several problems and to recognize the possibility that the same law is not necessarily applicable to all of them. American courts lack easy familiarity with this technique, and an exposition of it might have been very rewarding.

19 Mr. Nussbaum estimates that "the total of articles and monographs on renvoi and qualification is not far below the number of all other articles and monographs on choice-of-law." Op. cit. supra note *, at xo2. 
In a book covering such a large field a reviewer will also inevitably find points where he disagrees with the author. To enumerate them would hardly serve a good purpose, but this reviewer cannot omit a reference to the one major objection which he has to the author's method. With the rejection of those fanciful theories upon which Mr. Beale and his European counterparts have been trying to establish systems of conflict of laws, this reviewer wholeheartedly agrees. With the notion, however, that we can dispense with all theory and that we can simply be pragmatic and search for the most appropriate solution for every single problem, he disagrees, to the extent at least that he maintains the necessity of having a standard by which the appropriateness of a solution can be determined. By advocating some and rejecting other solutions, the author constantly makes value judgments. What is his standard of evaluation? He does not tell us. True, we feel that most of the solutions advocated are adequate and just. Obviously, in his opinions the author was guided by his feeling, his "judicial hunch," which he has so admirably well developed in his extensive practical experience. But is it not one of the tasks of legal science, perhaps its most eminent task, to articulate that hunch and to express it in words? It is true, of course, that complete articulation can never be achieved: The artistic element will always have to play a role in the administration of justice. But we should try to articulate our hunch as far as possible, and thus not only make it applicable by others, but also subject to conscious criticism.

The writers whose theories Professor Nussbaum so vigorously refutes have all been puzzled by one problem, the problem of knowing why it is that certain cases are decided by courts in accordance with foreign law. The reason for this phenomenon is by no means self-evident. Regularly a court decides its cases by its own law. Why does it occasionally resort to the rules of a foreign law? The internationalists thought that nations were compelled to do so by international law. That answer has been shown to be wrong; yet the question remains, and only by knowing the reason why foreign law is applied in certain cases can we determine whether in a given case that reason exists and, consequently, under what law the case should be decided. Without some answer to that question we cannot decide any problem of choice-of-law. The only choice is whether we shall content ourselves with feeling it vaguely or whether we shall try to articulate it. In the opinion of this reviewer, the factor which has caused the courts of all countries to decide certain cases under foreign rather than under domestic law, is the desire to prevent the disappointment of justified expectations. Domestic law, the ordinary law of 
the court, is not applied where its application would take the parties by surprise and would upset their legitimate expectations. For this reason courts do not apply their own law to a tort wholly committed abroad or to a transaction which has no contacts with the forum other than that of the action's having been brought there. The vague recognition of this policy obviously explains the author's preference for applying to an agreement the law which the parties intended rather than the law of the place of contracting, the application of which may never have been envisaged by the parties. Without that assumption it remains unexplained why the intent theory should be at all preferred over the place of contracting theory. The policy of protecting justified expectations does not explain all the phenomena of the conflict of laws, however; courts have been moved by other policies, especially policies which limit the application of the former.

In several places Professor Nussbaum expresses disagreement with Professor Cook. Of course, Mr. Cook's opinions were known to him only from the law review articles, and it is possible that Mr. Nussbaum might have found himself in greater agreement with that author if he had had the opportunity to see his work in its present coherent form. Possibly, however, the disagreement might then have been even more explicit. Mr. Cook's method is characterized by his insistence upon the articulation of our assumptions and the use of unifying theories, not, it is true, as incontrovertible axioms, but at least as working hypotheses. Mr. Nussbaum's disdain, on the other hand, of such rigorously logical methods may appeal to many readers. Certainly his pragmatic approach is in accord with the traditional methods of the common law. 